\title{
Investigations on Some Physicochemical Parameters of Demirköprü Dam Lake (Manisa, Turkey)
}

\author{
Saniye Türk Çulha ${ }^{1 *}$, Mirati Erdoğuş² \\ ${ }^{1}$ Izmir Katip Çelebi University, Faculty of Fisheries, Department of Hydrobiology, 35620 İzmir, Turkey \\ ${ }^{2}$ Near East University, Department of Environmental Education and Management, Lefkoşa, TRNC
}

\section{A R T I C LE IN F O}

\section{Research Article}

Received 01 June 2018

Accepted 06 July 2018

Keywords:

Water quality

Trophic level

Eutrophic

Hypereutrophic

Dam lake

Demirköprü.

*Corresponding Author:

E-mail: trksanye@gmail.com

\begin{abstract}
A B S T R A C T
This study was carried out at 3 different stations in Demirköprü Dam Lake, Köprübaş1, situated in Manisa, between June 2015 - May 2016. Samples collected from the surface and the bottom of the lake were analyzed seasonally in terms of depth $(\mathrm{m})$, temperature $\left({ }^{\circ} \mathrm{C}\right)$, dissolved oxygen (DO), $\mathrm{pH}$, salinity $(\%)$, total dissolved solids (TDS), electrical conductivity (EC), secchi disk depth (SD), suspended solid matter (SSM), particulate organic matter (POM), particulate inorganic matter (PIM), ammonium nitrogen $\left(\mathrm{NH}_{4}{ }^{+}-\right.$ $\mathrm{N})$, nitrite nitrogen $\left(\mathrm{NO}_{2}^{-}-\mathrm{N}\right)$, nitrate nitrogen $\left(\mathrm{NO}_{3}^{-}-\mathrm{N}\right)$, phosphate phosphorus $\left(\mathrm{PO}_{4}^{-3}-\mathrm{P}\right)$, silica $\left(\mathrm{SiO}_{2}\right)$ and Chlorophyll-a parameters. As a result of this study, according to Inland Water Quality Standards defined in Surface Water Quality Management Regulations (SWQMR) Demirköprü Dam Lake can be considered; Class-I quality according to measured temperature $\left(15 \pm 1.3^{\circ} \mathrm{C}\right), \mathrm{NO}_{2}{ }^{-}-\mathrm{N}(0.010 \pm 0.003 \mathrm{mg} / \mathrm{l})$ and $\mathrm{NO}_{3}{ }^{-}-\mathrm{N}(0.04 \pm 0.01$ $\mathrm{mg} / \mathrm{l})$ values; Class-II quality according to measured DO $(6.86 \pm 0.90 \mathrm{mg} / \mathrm{l}), \mathrm{EC}(591 \pm 6.4$ $\mu \mathrm{S} / \mathrm{cm}), \mathrm{SSM}(5.90 \pm 6.40 \mathrm{mg} / \mathrm{l}), \mathrm{NH}_{4}{ }^{+}-\mathrm{N}(0.30 \pm 0.09 \mathrm{mg} / \mathrm{l})$ and $\mathrm{PO}_{4}{ }^{-3}-\mathrm{P}(0.08 \pm 0.01 \mathrm{mg} / \mathrm{l})$ values; Class-III quality according to measured $\mathrm{pH}(8.72 \pm 0.09)$ values. Also, according to Turkish Boundary Values of Trophic Classification System of Lakes, Ponds and Reservoirs; the trophic level of the lake is considered eutrophic in regard to $\mathrm{PO}_{4}{ }^{-3}$ - and $\mathrm{SD}$ values and hypereutrophic in regard to Chlorophyll-a values.
\end{abstract}

DOI: https://doi.org/10.24925/turjaf.v6i9.1267-1273.2032

\section{Introduction}

As the most widespread form of water pollution, eutrophication and its negative effects on aquatic ecosystems are not only significant problem for natural habitats (lakes and rivers etc.) but also artificial reservoirs or dam lakes (Starling, 1993; Cai and Hu, 2006; Borduqui and Ferragut, 2012). Unlike natural lakes, external nutrient loadings in reservoirs are generally high, variable and unpredictable due to larger drainage basins, more human activity, and greater water level changes (Thornton et al., 1990). Dam lakes are built for producing energy, protecting from floods and obtaining irrigation water in developing countries and have a greater importance than thermal and nuclear power plants in terms of their environmental effects (Küçükyılmaz et al., 2010). Main criteria used for determining the pollution in dam lakes are physicochemical and biological factors and there are many studies on this subject (Sömek et al., 2005; Bulut et al., 2011; Varol 2013; Varol 2015; Mutlu et.al., 2018). There are 706 dam lakes in Turkey (DSI, 2015). One of these dam lakes, Demirköprü Dam Lake was built between 1954-1960 for energy, irrigation and flood control. Demirköprü Dam Lake was made on the Gediz
River. The main water sources of the dam lake are Gediz River and Demirci stream. It has been reported that the Gediz river basin is under the pressure of various pollutants originated from industrial, agricultural and domestic waste discharges (Delibacak et al., 2002). Additionally, commercial fisheries and aquaculture activities have been performed in the dam lake since 2003 (Anonymous, 2014). The only study associated with the water quality of Demirköprü Dam Lake was conducted by Tenekecioğlu (2011). In this study, it was aimed to determine the present water quality and trophic level of Demirköprü Dam Reservoir more extensively.

\section{Material and Method}

Demirköprü Dam Lake is located at coordinates $38^{\circ}$ $36^{\prime} 59.80^{\prime \prime} \mathrm{N}$ and $28^{\circ} 18^{\prime} 40.69^{\prime \prime} \mathrm{E}$ in Manisa-Turkey (Figure 1). This study was carried out seasonally at 3 different stations (surface and bottom) in Demirköprü Dam Lake between June 2015 - May 2016. Temperature $\left({ }^{\circ} \mathrm{C}\right)$ dissolved oxygen (DO), $\mathrm{pH}$, total dissolved solids (TDS), electrical conductivity (EC) and Secchi disk depth 
(SD) were measured in situ. Suspended solid matter (SSM), particulate organic matter (POM) and particulate inorganic matter (PIM) were analyzed with gravimetric methods (Stirling, 1985). Analyses of nitrogen forms, phosphate phosphorus, silica and Chlorophyll-a have been performed using spectrophotometer (Strickland and Parsons, 1972; Wood, 1975; Parsons et al., 1984; Egemen and Sunlu, 2003). Water quality and trophic level of the dam lake have been determined referring to Turkish Surface Water Quality Management Regulation and the Boundary Values of Trophic Classification System of Lakes, Ponds and Reservoirs (Table 1). In the study, the data were classified according to months and stations, checked in terms of their normality and homogeneity and then their average values and standard errors were calculated. Significance test between stations and seasons was conducted with Two-Way ANOVA and Duncan test was applied in cases where the difference was statistically significant. All the statistical analyses were carried out in the computer environment using the Microsoft Excel Program and SPSS 15.0 C package software (Sümbüloğlu and Sümbüloğlu, 2010).

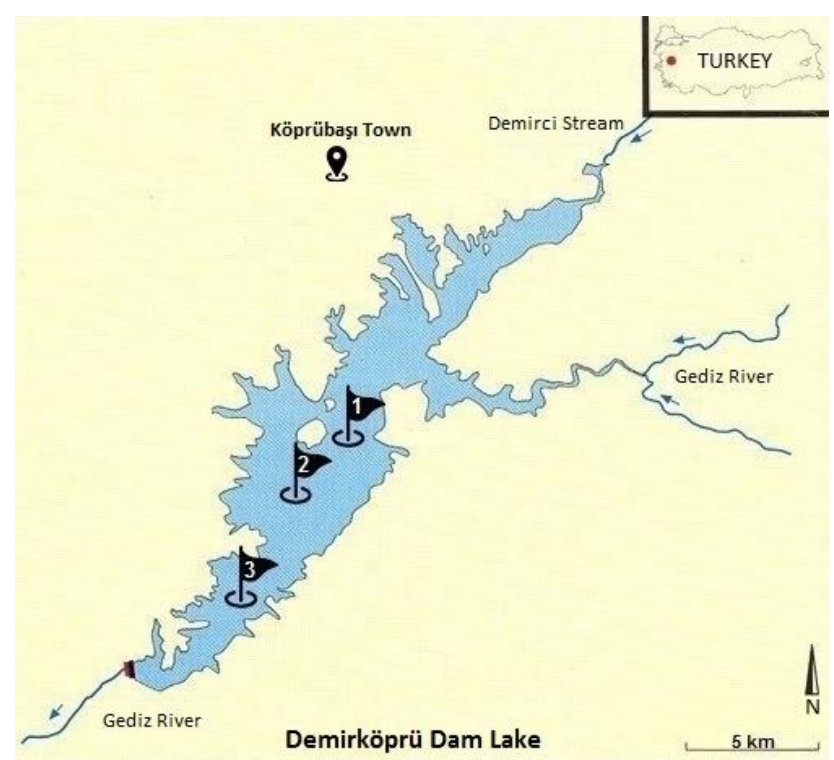

Figure 1 The study area and sampling stations

Table 1 Turkish Boundary Values of Trophic Classification System of Lakes, Ponds and Reservoirs (SWQMR, 2015).

\begin{tabular}{ll|ccc}
\hline \multicolumn{2}{c|}{ Trophic State } & $\begin{array}{c}\text { TP } \\
(\mu \mathrm{g} / \mathrm{L})\end{array}$ & $\begin{array}{c}\text { Chlorophyll- } \\
\mathrm{a}(\mu \mathrm{g} / \mathrm{L})\end{array}$ & $\begin{array}{c}\text { Secchi } \\
\text { Depth }(\mathrm{m})\end{array}$ \\
\hline Oligotroph & $\mathrm{O}$ & $<10$ & $<3.5$ & $>4$ \\
Mesotroph & $\mathrm{M}$ & $10-30$ & $3.5-9.0$ & $4-2$ \\
Eutroph & $\mathrm{E}$ & $31-100$ & $9.1-25.0$ & $1.9-1$ \\
Hypertroph & $\mathrm{H}$ & $>100$ & $>25.0$ & $<1$ \\
\hline
\end{tabular}

\section{Results and Discussion}

In this study, physicochemical parameters of bottom and surface waters sampled from 3 stations were evaluated seasonally. During seasonal changes, all parameters measured were statistically significant $(\mathrm{P}>0.05)$. Temperature is a very important parameter for aquatic life in that it affects the rate of biochemical reactions that occur in the aquatic environment and the solubility of gases by altering the viscosity and density of the water. It is also important in reproduction, nutrition and metabolic activities, increasing the biological activity rate and reducing oxygen saturation (Kirankaya and Ekmekci, 2005). In this study, annual mean water temperature obtained from measurements made from 3 stations was determined as $15.0 \pm 1.3^{\circ} \mathrm{C}$. Similar water temperature values were obtained at Almus Dam Lake $\left(14.8^{\circ} \mathrm{C}\right)$ and Derbent Dam Lake $\left(15.6^{\circ} \mathrm{C}\right)$ (Buhan et al., 2010; Taş, 2006). The highest temperature was measured in surface water in the summer $\left(26.3^{\circ} \mathrm{C}\right)$ and the lowest temperature was measured in bottom water in the spring $\left(8.5^{\circ} \mathrm{C}\right)$ when the temperature stratification started to take place. In the study, a clear temperature stratification was observed in the summer between temperatures of the surface and bottom water. During the winter season when the mixture is in the process, no significant temperature difference was observed between surface and bottom water. It has been stated that there is an apparent decrease in vertical curve of oxygen in eutrophic lakes from the surface to the hypolimnion at summer, and its primary reasons are temperature and organic matter oxidation (Tanyolaç, 2009). A similar result was observed by Tenekecioğlu (2011) in Demirköprü Dam Lake (26.5$6.0^{\circ} \mathrm{C}$ ) and by Sömek (2011) in Adigüzel Dam Lake (20.0-8. $\left.2^{\circ} \mathrm{C}\right)$. Considering the criteria specified by SWQMR (2015); Demirköprü Dam Lake is in the category of I. Class water quality in terms of average water temperature values in all stations and depths.

The DO value in the aquatic environment varies depending on the temperature, the photosynthesis rate of the plants, the trophic level of the lakes, the altitude, the depth and the formation of the thermocline layer (Akbulut and Y1ldız, 2001, Tenekecioğlu, 2011). In this study, the mean annual DO value in lake water was determined as $6.86 \pm 0.90 \mathrm{mg} / \mathrm{l}$, the mean value of the surface water was $10.23 \mathrm{mg} / \mathrm{l}$ and the mean value of the bottom water was $3.5 \mathrm{mg} / \mathrm{l}$. In the summer and autumn seasons the DO values in the bottom waters of all stations were low. Tenekecioğlu (2011), who performed a study in the same region, also measured DO values in bottom waters as low. The researcher reported that the reason for this was due to the consumption of oxygen during decomposition of hypolimnion detritus by saprophytic bacteria and the interruption of the transfer of matter and energy between epilimnion and hypolimnion layers resulted from thermocline layer that acts as a barrier. Another similar result was observed at the Adigüzel Dam Lake. It was stated that the DO value decreases beginning from $10 \mathrm{~m}$ to $1 \mathrm{mg} / \mathrm{l}$ or less in periods when the summer stratification continues and anoxic environment is formed (Sömek 2011). Sömek (2011) also stated that this was due to the rapid consumption of dissolved oxygen by metabolic activities of bacteria, and that the vertical curve of oxygen in eutrophic lakes showed a significant decrease from surface to hypolimnion in summer, and that these events occurred due to temperature and oxidation of organic matter. In this study, DO value is thought to be decreased due to the same reasons. DO values in surface waters was higher in spring compared to other seasons. As the reason for this, it is considered that the DO value in the environment was increased due to the density of phytoplankton at that time. As is indicated by SWQMR 
(2015), comparing DO values with water quality parameter values; they are in the II. Class category without discriminating station and depth, I. Class category according to surface waters and III. Class category according to deep waters.

$\mathrm{pH}$ is a sign of acid or base properties of water and is one of the important factors affecting living in the aquatic environment. Aquatic creatures develop well in the $\mathrm{pH}$ range of 6.5 to 8.5 (Arrignon, 1976; Dauba, 1981). The annual average $\mathrm{pH}$ value determined in the lake water in study was $8.72 \pm 0.09$ and it was an alkaline structure. The average $\mathrm{pH}$ value determined in the spring season was higher than the other seasons. The $\mathrm{pH}$ of the water is generally balanced by the carbonate system. It was reported that the $\mathrm{pH}$ decreases when the equilibrium shifts to $\mathrm{CO}_{2}$ and $\mathrm{HCO}_{3}$, and the $\mathrm{pH}$ increases when it shifts towards $\mathrm{CO}_{3}$ (Göksu, 2015). The $\mathrm{pH}$ value in the Demirköprü Dam Lake is thought to increase due to the use of $\mathrm{CO}_{2}$ by phytoplankton in surface waters in the spring. The value of chlorophyll-a detected in the spring season also supports this situation. Similarly, Gürevin (2004) reported that the $\mathrm{pH}$ increase in the water is due to the decrease in the amount of $\mathrm{CO}_{2}$ in the environment resulted from the increase in phytoplankton density. Tenekecioğlu (2011) stated that the mean $\mathrm{pH}$ values of Demirköprü Dam Lake was between 7.70-8.80, that the buffer capacity of the lake water was high and that excessive $\mathrm{pH}$ fluctuations were not seen. Comparing $\mathrm{pH}$ values determined in the study with water capacity parameter values specified by SWQMR (2015); it is seen that surface waters are in the IV. Class category, deep waters I. Class category and all stations and depths III. Class category. In the same study conducted by Sarıyıldiz et al. (2008) in the same lake and in another study conducted by Küçükyılmaz et al. (2014) in Işıktepe Dam Lake, it was reported that $\mathrm{pH}$ value was in the III. Class category in general terms.

The sources of TDS are natural, domestic, industrial wastewater and substances from agricultural lands. The main ions contributing to the amount of TDS are carbonate, bicarbonate, chloride, sulphate, nitrate, sodium, potassium, calcium, magnesium etc. In addition, clay, silt, small particles in organic structure, inorganic substances, soluble organic compounds, plankton and other microscopic organisms constitute TDS (Taş and Çetin, 2011). Knowing the total amount of substances or minerals dissolved in natural waters is a useful parameter for defining the chemical content of water (Tanyolaç, 2009). The annual average TDS value obtained at Demirköprü Dam Lake is $590.29 \pm 6.4 \mathrm{mg} / \mathrm{l}$. TDS values in study were generally high in winter and low in summer (Table 2). Walling and Webb (1986) reported that TDS in water originated from rock and soil minerals. It is believed that the reason for the high TDS value in winter, due to atmospheric changes and terrestrial inputs carried by rainwater to the lake. The mean TDS value determined at Yamula Dam Lake was $1119 \mathrm{mg} / \mathrm{l}$ (Çevik and Elibol, 2009), which is considerably higher than the values determined at Demirköprü Dam Lake. According to SWQMR (2015) water quality parameter values, TDS is located in the II. class water category.
EC is an indication of the total dissolved solids in the water. EC changes depending on the geological structure and amount of precipitation (Bremond and Vuichard, 1973). In this study, the annual average EC value determined in the lake water is $591.4 \pm 6.4 \mu \mathrm{S} / \mathrm{cm}$. EC values measured at Demirköprü Dam Lake were high in winter and low in summer (Table 2). Increasing EC value in the winter season is thought to be due to terrestrial inputs carried by rainwater to the lake, and in the summer season due to the increase in temperature. Decreasing EC values during the summer may be caused by precipitation of major ions such as calcium from the surface to deeper (Varol, 2015). When the other dam lakes and this study are compared, it is seen that EC value in Gökgöl (1294.3 $\mu \mathrm{S} / \mathrm{cm})$ is higher and EC values $(619.2 \mu \mathrm{S} / \mathrm{cm})$ of Tenekecioğlu (2011) in the same lake is similar. EC value according to SWQMR (2015) water quality parameter values is in the II. class water category.

SSM is a parameter which, after a certain amount, usually causes physical contamination of water, clouding, condensation and toxicity, as well as damaging water organisms by decreasing the light permeability and oxygen content (Uslu and Türkman, 1987). According to SKKY (2004), the required SSM value for the eutrophication control of dam lakes is $5 \mathrm{mg} / \mathrm{l}$. The annual average SSM value determined at Demirköprü Dam Lake is $5.41 \pm 0.61 \mathrm{mg} / \mathrm{l}$. Generally, SSM values were high in spring and low in summer (Table 2). It is thought that the SSM values are high due to the increase of phytoplankton population and the terrestrial inputs carried by rainwater and snow melt. A similar case was also found in the Dicle Dam Lake (3.15 mg / 1) (Varol, 2015). Sarıyıldız et al. (2008) stated that SSM at Demirköprü Dam Lake entered in the polluted water category. It is considered that the high PIM values were originated from the surface waters resulted from the rainfall in winter while originated from the POM values of the increasing phytoplankton density in the spring (Table 2).

In this study, annual mean $\mathrm{NH}_{4}{ }^{+}-\mathrm{N}$ value determined in lake water is $0.30 \pm 0.09 \mathrm{mg} / \mathrm{l}$. It is thought that the reason for the relatively low detection of $\mathrm{NH}_{4}{ }^{+}-\mathrm{N}$ values in the Demirköprü Dam Lake during the spring season is that increasing phytoplankton biomass is consumed in this period as nutrients and the ammonium is converted to ammonia with increasing $\mathrm{pH}$. The $\mathrm{pH}$ in the water is a parameter that is effective in the conversion of ammonium into ionized or non-ionized ammonia. Increase or decrease of the $\mathrm{pH}$ in the water causes the ammonia to be very toxic (Howell and Baynes, 2004). The $\mathrm{pH}$ and chlorophyll-a values determined in the study also support this. The highest $\mathrm{NH}_{4}{ }^{+}-\mathrm{N}$ values were found in bottom waters in autumn (Table 2). This increase in bottom water may be due to the presence of an anoxic environment in the hypolimnion and the inability of the nitrification processes to occur. Similarly, Wetzel (1983) reported that ammonium is a main product resulting from the destruction of organic material by bacteria. Likewise, Uslu and Türkman (1987) stated that the toxic effect of ammonia may also be increased by the lack of oxygen, the increase in temperature and the presence of other toxic substances. It was also found in a study that there is a statistically negative correlation between ion concentrations of oxygen and ammonium (Mutlu and 
Aydın Uncumusaoğlu, 2018). The average $\mathrm{NH}_{4}{ }^{+}-\mathrm{N}$ value determined in the study is smaller than the value determined by Çevik and Elibol (2009) in Yamula Dam Lake $(0.460 \mathrm{mg} / \mathrm{l})$; greater than the value determined by Bulut et al. (2011) in Selevir Dam Lake $(0.063 \mathrm{mg} / \mathrm{l})$; and similar with the value determined by Buhan et al. (2010) in Almus Dam Lake $(0.290 \mathrm{mg} / \mathrm{l})$. General average value of $\mathrm{NH}_{4}{ }^{+}-\mathrm{N}$ is in the II. Class category. On the other hand, in the study by Sariyildiz et al. (2008) conducted with samples taken from the area where Gediz River flows into the same river, it was reported that $\mathrm{NH}_{4}{ }^{+}-\mathrm{N}$ value was in the IV. Class category according to SKKY (2004).

Table 2 Average and minimum-maximum values of physicochemical parameters and trophic classifications in the study area (nd: not detected).

\begin{tabular}{|c|c|c|c|c|c|c|c|c|c|c|}
\hline \multirow{2}{*}{\multicolumn{2}{|c|}{ Parameters }} & \multicolumn{2}{|c|}{ Summer } & \multicolumn{2}{|c|}{ Autumn } & \multicolumn{2}{|c|}{ Winter } & \multicolumn{2}{|c|}{ Spring } & \multirow{2}{*}{$\begin{array}{l}\text { Mean } \\
\text { Values }\end{array}$} \\
\hline & & $S$ & B & $\mathrm{S}$ & B & $S$ & B & $\mathrm{S}$ & B & \\
\hline \multirow{3}{*}{$\begin{array}{l}\text { Temp. } \\
\left({ }^{\circ} \mathrm{C}\right)\end{array}$} & $\mathrm{Av}$ & 26.3 & 13.0 & 22.2 & 19.8 & 10.4 & 9.1 & 16.7 & 8.5 & \multirow{3}{*}{$15 \pm 1.3$} \\
\hline & $\mathrm{Mn}$ & 25.7 & 9.8 & 22.0 & 10.4 & 10.3 & 8.7 & 16.6 & 8.2 & \\
\hline & $\mathrm{Mx}$ & 26.8 & 18.5 & 22.4 & 20.4 & 10.5 & 9.7 & 17.2 & 9.1 & \\
\hline \multirow{3}{*}{$\begin{array}{l}\text { DO } \\
(\mathrm{mg} / \mathrm{L})\end{array}$} & $\mathrm{Av}$ & 9.61 & 1.00 & 7.46 & 2.14 & 8.98 & 6.58 & 14.87 & 4.27 & \multirow{3}{*}{$6.86 \pm 0.90$} \\
\hline & $\mathrm{Mn}$ & 9.44 & 0.90 & 7.21 & 0.28 & 7.93 & 5.47 & 14.57 & 3.46 & \\
\hline & $\mathrm{Mx}$ & 9.78 & 1.19 & 7.74 & 5.67 & 10.21 & 8.44 & 15.08 & 4.72 & \\
\hline \multirow{3}{*}{$\mathrm{pH}$} & Av & 9.22 & 8.39 & 8.96 & 8.24 & 8.73 & 8.50 & 9.42 & 8.33 & \multirow{3}{*}{$8.72 \pm 0.09$} \\
\hline & $\mathrm{Mn}$ & 9.12 & 8.37 & 8.89 & 7.99 & 8.66 & 8.35 & 9.41 & 8.25 & \\
\hline & $\mathrm{Mx}$ & 9.27 & 8.59 & 9.05 & 8.70 & 8.78 & 8.72 & 9.42 & 8.39 & \\
\hline \multirow{3}{*}{$\begin{array}{l}\mathrm{EC} \\
(\mu \mathrm{S} / \mathrm{cm})\end{array}$} & Av & 525.56 & 592.00 & 585.67 & 605.22 & 619.56 & 619.22 & 566.89 & 610.67 & \multirow{3}{*}{$591 \pm 6.4$} \\
\hline & $\mathrm{Mn}$ & 522.67 & 566.00 & 579.67 & 579.67 & 618.33 & 617.67 & 565.33 & 609.67 & \\
\hline & $\mathrm{Mx}$ & 527.33 & 605.33 & 589.67 & 609.67 & 623.67 & 621.00 & 568.00 & 612.67 & \\
\hline \multirow{3}{*}{$\begin{array}{l}\text { TDS } \\
(\mathrm{mg} / / \mathrm{L})\end{array}$} & $\mathrm{Av}$ & 524.78 & 590.89 & 585.11 & 605.44 & 619.44 & 619.22 & 566.78 & 610.67 & \multirow{3}{*}{$590 \pm 6.4$} \\
\hline & $\mathrm{Mn}$ & 523.00 & 564.67 & 578.00 & 597.67 & 618.33 & 617.67 & 565.33 & 609.67 & \\
\hline & $\mathrm{Mx}$ & 527.00 & 604.38 & 589.67 & 610.00 & 620.67 & 621.00 & 568.00 & 612.67 & \\
\hline \multirow{3}{*}{$\begin{array}{l}\mathrm{SSM} \\
(\mathrm{mg} / \mathrm{L})\end{array}$} & Av & 5.37 & 2.93 & 5.47 & 4.81 & 3.53 & 6.46 & 10.16 & 4.52 & \multirow{3}{*}{$5.41 \pm 0.61$} \\
\hline & $\mathrm{Mn}$ & 4.90 & 2.23 & 2.80 & 1.73 & 2.87 & 3.30 & 8.80 & 2.90 & \\
\hline & $\mathrm{Mx}$ & 6.27 & 4.20 & 8.03 & 10.47 & 4.00 & 10.30 & 11.27 & 6.17 & \\
\hline \multirow{3}{*}{$\begin{array}{l}\text { POM } \\
(\mathrm{mg} / \mathrm{L})\end{array}$} & $\mathrm{Av}$ & 3.73 & 1.61 & 2.53 & 1.78 & 1.97 & 1.84 & 7.60 & 1.31 & \multirow{3}{*}{$2.80 \pm 0.42$} \\
\hline & $\mathrm{Mn}$ & 3.50 & 1.27 & 1.97 & 1.20 & 1.90 & 1.47 & 6.63 & 0.93 & \\
\hline & $\mathrm{Mx}$ & 3.90 & 2.27 & 3.10 & 2.47 & 2.03 & 2.13 & 8.13 & 1.93 & \\
\hline \multirow{3}{*}{$\begin{array}{l}\text { PIM } \\
(\mathrm{mg} / \mathrm{L})\end{array}$} & $\mathrm{Av}$ & 1.63 & 1.38 & 2.93 & 3.07 & 1.57 & 4.61 & 2.54 & 3.21 & \\
\hline & $\mathrm{Mn}$ & 1.10 & 0.77 & 0.83 & 0.60 & 0.83 & 1.83 & 2.17 & 1.97 & $2.62 \pm 0.42$ \\
\hline & $\mathrm{Mx}$ & 2.37 & 1.93 & 4.93 & 8.03 & 2.03 & 8.17 & 3.20 & 4.23 & \\
\hline & $\mathrm{Av}$ & 3.505 & 7.843 & 4.045 & 7.966 & 4.539 & 6.770 & 7.275 & 7.059 & \\
\hline$S$ & $\mathrm{Mn}$ & 3.287 & 5.217 & 3.966 & 4.624 & 4.350 & 5.565 & 7.134 & 6.950 & $6.13 \pm 0.42$ \\
\hline & $\mathrm{Mx}$ & 3.696 & 9.341 & 4.624 & 9.692 & 4.709 & 7.481 & 7.381 & 7.230 & \\
\hline & $\mathrm{Al}$ & 0.019 & 0.341 & 0.014 & 1.175 & 0.109 & 0.466 & 0.015 & 0.213 & \\
\hline & $\mathrm{Mn}$ & 0.015 & 0.153 & 0.010 & 0.306 & 0.095 & 0.156 & 0.008 & 0.009 & $0.30 \pm 0.09$ \\
\hline & $\mathrm{Mx}$ & 0.024 & 0.439 & 0.018 & 1.736 & 0.123 & 0.703 & 0.029 & 0.026 & \\
\hline & $\mathrm{Av}$ & 0.003 & 0.040 & 0.003 & 0.006 & 0.005 & 0.011 & 0.005 & 0.006 & \\
\hline & $\mathrm{Mn}$ & 0.003 & 0.023 & 0.002 & 0.003 & 0.004 & 0.009 & 0.005 & 0.004 & $0.010 \pm 0.003$ \\
\hline & $\mathrm{Mx}$ & 0.003 & 0.074 & 0.004 & 0.012 & 0.006 & 0.013 & 0.006 & 0.007 & \\
\hline & Av & 0.005 & 0.120 & & & 0.037 & 0.049 & 0.004 & 0.116 & \\
\hline$-\mathrm{N}$ & $\mathrm{Mn}$ & 0.003 & 0.076 & nd & nd & 0.032 & 0.044 & 0.002 & 0.107 & $0.04 \pm 0.01$ \\
\hline & $\mathrm{Mx}$ & 0.007 & 0.154 & & & 0.042 & 0.054 & 0.006 & 0.129 & \\
\hline & $\mathrm{Av}$ & $0.021^{\mathrm{M}}$ & $0.083^{\mathrm{E}}$ & $0.021^{\mathrm{M}}$ & $0.186^{\mathrm{H}}$ & $0.063^{\mathrm{E}}$ & $0.130^{\mathrm{H}}$ & $0.034^{\mathrm{E}}$ & $0.087^{\mathrm{E}}$ & \\
\hline $\mathrm{PO}_{4}-\mathrm{P}$ & $\mathrm{Mn}$ & $0.018^{\mathrm{M}}$ & $0.028^{\mathrm{E}}$ & $0.019^{\mathrm{M}}$ & $0.064^{\mathrm{H}}$ & $0.053^{\mathrm{E}}$ & $0.071^{\mathrm{H}}$ & $0.025^{\mathrm{E}}$ & $0.068^{\mathrm{E}}$ & $0.08 \pm 0.01^{\mathrm{E}}$ \\
\hline & $\mathrm{Mx}$ & $0.024^{\mathrm{M}}$ & $0.130^{\mathrm{E}}$ & $0.024^{\mathrm{M}}$ & $0.262^{\mathrm{H}}$ & $0.061^{\mathrm{E}}$ & $0.164^{\mathrm{H}}$ & $0.042^{\mathrm{E}}$ & $0.097^{\mathrm{E}}$ & \\
\hline Chloroph & Av & $28^{\mathrm{H}}$ & $3.67^{\mathrm{M}}$ & $28.35^{\mathrm{H}}$ & $11.81^{\mathrm{E}}$ & $17.28^{\mathrm{E}}$ & $3.53^{\mathrm{M}}$ & $147.03^{\mathrm{H}}$ & $5.26^{\mathrm{M}}$ & \\
\hline yll-a & $\mathrm{Mn}$ & $22^{\mathrm{H}}$ & $1^{\mathrm{M}}$ & $22^{\mathrm{H}}$ & $2^{\mathrm{E}}$ & $15^{\mathrm{E}}$ & $3^{\mathrm{M}}$ & $135^{\mathrm{H}}$ & $5^{\mathrm{M}}$ & $30.58 \pm 9.51^{\mathrm{H}}$ \\
\hline$(\mu \mathrm{g} / \mathrm{L})$ & $\mathrm{Mx}$ & $40^{\mathrm{H}}$ & $9^{\mathrm{M}}$ & $33^{\mathrm{H}}$ & $32^{\mathrm{E}}$ & $20^{\mathrm{E}}$ & $4^{\mathrm{M}}$ & $162^{\mathrm{H}}$ & $6^{\mathrm{M}}$ & \\
\hline $\mathrm{SD}(\mathrm{m})$ & & $2.06 \pm$ & $.14^{\mathrm{M}}$ & $1.88 \pm$ & $0.17^{\mathrm{E}}$ & $2.79 \pm$ & $.17^{\mathrm{M}}$ & $1.12 \pm$ & $.02^{\mathrm{E}}$ & $1.96 \pm 0.21^{\mathrm{E}}$ \\
\hline
\end{tabular}

S: Surface, B: Bottom, Av: Average, Mn: Minimum, Mx: Maximum, O: Oligotroph, M: Mesotroph, E: Eutroph, H: Hypertroph 
$\mathrm{NO}_{2}^{--} \mathrm{N}$ is an intermediate product which occurs as aresult oxidation of ammonia or reduction of nitrate in the oxidation reaction of ammonia and does not accumulate in the environment. Nitrite originates from the biodegradation of some organic proteins (Giritlioğlu, 1975; Boyd and Tucker, 1998). The mean $\mathrm{NO}_{2}{ }^{--} \mathrm{N}$ value in this study is $0.010 \pm 0.003 \mathrm{mg} / \mathrm{l}$. Buhan et al. (2010) reported no pollution due to $\mathrm{NO}_{2}^{--} \mathrm{N}(0.011 \mathrm{mg} / \mathrm{l})$ values in the Almus Dam Lake. It has been determined that $\mathrm{NO}_{2}^{-}$ - $\mathrm{N}$ values determined in Demirköprü Dam Lake in summer are higher than other seasons. This difference is thought to be due to the rapid nitrite oxidation of the ammonium unused by phytoplankton (Egemen and Sunlu, 2003). Tenekecioğlu (2011) measured highest nitrite value at Demirköprü Dam Lake in July. According to the SWQMR (2015) water quality parameters, the values of $\mathrm{NO}_{2}{ }^{--} \mathrm{N}$ are in I. class water category.

According to SWQMR (2015), the amount of $\mathrm{NO}_{3}^{--\mathrm{N}}$ significantly increases during periods of heavy precipitation and organic pollution. As a result of washing the agricultural land of the rain water, the nitrate, which easily dissolves in the water, mixes with the natural water environment. $\mathrm{NO}_{3}{ }^{--} \mathrm{N}$, which occurs as a byproduct of bacterial nitrification, is destroyed by consumption of plants and reduction to ammonia (Giritlioğlu, 1975). The average $\mathrm{NO}_{3}^{--} \mathrm{N}$ value determined in the study is $0.04 \pm 0.01 \mathrm{mg} / \mathrm{l}$. These $\mathrm{NO}_{3}^{--} \mathrm{N}$ data are less than the values of Demirköprü Dam Lake $(9.06 \mathrm{mg} / \mathrm{l})$ and Adıgüzel Dam Lake (0.40 mg/l) (Tenekecioğlu, 2010; Sömek, 2011), and higher than Selevir Dam Lake (0.006 $\mathrm{mg} / \mathrm{l}$ ) (Bulut et al., 2011). In addition, $\mathrm{NO}_{3}{ }^{--} \mathrm{N}$ values determined in Demirköprü Dam Lake in spring and summer are higher than other seasons. This difference is thought to be due to the acceleration of the nitrification bacteria's activities with increasing water temperature above $15^{\circ} \mathrm{C}$ in the spring and summer seasons. A similar result was found by Ayvaz et al. (2011) in Afşar Dam Lake. According to the SWQMR (2015) water quality parameters, the values of $\mathrm{NO}_{3}^{--} \mathrm{N}$ are in I. class water category.

Phosphorus is found in relatively small quantities in uncontaminated natural waters and determines the productivity of lakes (Tepe and Boyd, 2003). In contrast to nitrogen, which has many forms in lake systems, the most apparent form of inorganic phosphorus is orthophosphate. In freshwater more than $90 \%$ of phosphorus is present in the cells of livings as organic phosphate (Wetzel, 1983). Ortho-phosphate anion is the basic constituent of all organic phosphorus compounds (Uslu and Turkman, 1987). The average $\mathrm{PO}_{4}{ }^{-3}-\mathrm{P}$ value determined in the Demirköprü Dam Lake is $0.08 \pm 0.01$ $\mathrm{mg} / \mathrm{l}$. The highest values were found in autumn in bottom water $(0.186 \mathrm{mg} / \mathrm{l})$, while the lowest values were found in surface water in summer and autumn $(0.21 \mathrm{mg} / \mathrm{l})$ (Table 2 ). It was determined that winter season differs from other seasons in terms of $\mathrm{PO}_{4}^{-3}-\mathrm{P}$ values. Source of $\mathrm{PO}_{4}^{-3}-\mathrm{P}$ in Demirköprü Dam lake is thought to be due to the geological structure of the lake, the nutrients coming from the Gediz River and the surface waters coming from the terrestrial environments with rain water because of the inclination the area. Wetzel, (2001) reported that the main source of phosphorus in the areas where human activities are not directly affecting the nutrient quantities is reach of phosphorus in rock and soil structure by surface flows to the lake. Tenekecioğlu (2011) and Anonymous (2014) obtained similar results in studies conducted at different times in the same dam lake. In additional, main source of $\mathrm{PO}_{4}{ }^{-3}-\mathrm{P}$ detected in Demirköprü Dam Lake were suggested to be Gediz River under the pressure of various pollutants and releasing of phosphorus from the dam lake sediment to the water. In the study, this situation is supported with relatively higher $\mathrm{PO}_{4}^{-3}-\mathrm{P}$ in the deep waters compared to the surface waters and low $\mathrm{DO}$ values in hypolimnion. Comparing $\mathrm{PO}_{4}{ }^{-3}-\mathrm{P}$ values determined in Demirköprü Dam Lake with water quality parameter values specified by SWQMR (2015); it is seen that they are included in the II. Class category and in the eutrophic class according to the Boundary Values of Trophic Classification System of Lakes, Ponds and Reservoirs. The studies being conducted report that many lakes in Turkey have a eutrophic structure in terms of total amount of phosphorus (Küçükyılmaz et al., 2014; Taş, 2006; Alpaslan et al., 2015).

Silica is not present as an element in freshwater yet it is usually in the form of silicon dioxide. More than $60 \%$ of the stone and land on the earth's surface contains silicon dioxide $\left(\mathrm{SiO}_{2}\right)$. Considering this ratio, it can be said that $\mathrm{SiO}_{2}$ rich waters are not polluted. It is natural that it has high density in the water of the lakes in the siliceous sediments. (Tanyolaç, 2009). In natural waters, silicon is 1-80 mg/l (Tepe et al., 2006). The average $\mathrm{SiO}_{2}$ value in Demirköprü Dam Lake was determined as $6.13 \pm 0.42 \mathrm{mg} / \mathrm{l}$. Similar to these values, Sömek (2011) found $\mathrm{SiO}_{2}$ value between 1.02-7.71 mg/l in Adigüzel Dam Lake, Saadoun et al. (2010) reported that the $\mathrm{SiO}_{2}$ value of the Wadi Al-Arab Dam in Bulgaria varies between 2.33-7.60 mg/l. Egemen and Sunlu (2003) stated that in the spring season when the amount of diatom is high, the silica concentration is very low and is high in the winter season when the photosynthesis activity is low. However, in this study, it is considered that the main source of silica, which is at the maximum level in the spring season, is derived from terrestrial inputs due to precipitation.

Chlorophyll-a is a photosynthetic pigment present in all phytoplanktonic organisms. Nutrient production is possible by chlorophyll through photosynthesis and chemosynthesis. In a freshwater ecosystem, the first ring of the food chain is phytoplanktonic organisms and plants. The amount of chlorophyll-a is therefore the most important indicator of phytoplankton biomass and productivity in a lake (Çevik and Elibol, 2009). Chlorophyll-a values determined in Demirköprü Dam Lake were inversely proportional with nutrient elements, and it reached to higher values in spring season (147.03 $\mu \mathrm{g} / \mathrm{l})$ while it was detected in lower values in winter season $(3.53 \mu \mathrm{g} / \mathrm{l})$ with lower production. In this period, bloom of Cyanobacteria and blue-green coloring were observed in the surface water. The mean Chlorophyll-a was measured as $30.58 \pm 9.51 \mu \mathrm{g} / 1$ in this study. This value was calculated by by Ayvaz et al. (2011) in Afşar Dam Lake (49.5 $\mu \mathrm{g} / \mathrm{l})$ and by Tenekecioğlu (2011) in Demirköprü Dam Lake (1.12 $\mu \mathrm{g} / \mathrm{l})$ Demirköprü Dam Reservoir are higher than the average Chlorophyll-a values. Average Chlorophyll-a amount determined in Demirköprü Dam Lake is in the hypereutrophic class 
according to the SWQMR (2015) Boundary Values of Trophic Classification System of Lakes, Ponds and Reservoirs.

SD depth is a simple method used to determine luminous transmittance or transparency of the water and is one of the important parameters used in determining the trophic structure of the lake. Luminous transmittance of the water is crucial in terms of the amount of light used by phytoplankton and other water plants that make up the first ring of the organic food chain in the aquatic environment (Cirik and Cirik, 1999). The seasonally adjusted SD value is $1.96 \pm 0.21 \mathrm{~m}$. The highest SD depth was measured in winter and the lowest in spring (Table 2). This difference between the seasons is thought to be due to the increase resulted from the increase in the depth due to the river waters that feed the dam lake, while the decrease is due to transportation of SSM load resulted from precipitation and snow melt. When the chlorophyll-a values are high, the depth of SD is low and when the chlorophyll-a is low, SD depth is high (Varol, 2013). Tenekecioğlu (2011) expressed similar comments in his study in the same region. The SD values obtained at Demirköprü Dam Lake are eutrophic according to SWQMR (2015) Limit Values of Trophic Classification System in Lakes, Ponds and Dam Lakes. This result is supported by in desk values indicating that SD depth is 14 m eutrophic (Taylor et al., 1980, Hakanson and Jansson, 1983).

Consequently, primary factors negatively affecting the water quality of Demirköprü Dam Lake are; transition of a branch of Gediz River to the dam lake and waters carried by Demirci Stream to the region, mixture of rain waters and surface waters (agricultural areas) into the lake due to the sloping land around the lake and geological structure of the lake. According to SWQMR (2015); Demirköprü Dam Lake is in the I. Class category in terms of the values of average temperature $\left(15 \pm 1.3^{\circ} \mathrm{C}\right), \mathrm{NO}_{2}^{-}-\mathrm{N}$ $(0.010 \pm 0.003 \mathrm{mg} / \mathrm{l})$ and $\mathrm{NO}_{3}{ }^{-}-\mathrm{N}(0.04 \pm 0.01 \mathrm{mg} / \mathrm{l})$, II. Class category in terms of the values of DO $(6.86 \pm 0.90$ $\mathrm{mg} / \mathrm{l})$, EC $(591 \pm 6.4 \mu \mathrm{S} / \mathrm{cm})$, TDS $(5.90 \pm 6.40 \mu \mathrm{mg} / \mathrm{l})$, $\mathrm{NH}_{4}{ }^{+}-\mathrm{N}(0.30 \pm 0.09 \mathrm{mg} / \mathrm{l})$ and $\mathrm{PO}_{4}{ }^{-3}-\mathrm{P}(0.08 \pm 0.01 \mathrm{mg} / \mathrm{l})$ and in the III. Class category in terms of $\mathrm{pH}$ value (8.72 \pm 0.09$)$. According to SWQMR (2015) Boundary Values of Trophic Classification System of Lakes, Ponds and Reservoirs; trophic level of the lake is eutrophic in terms of the values of $\mathrm{PO}_{4}^{-3}-\mathrm{P}$ and SD and hypereutrophic in terms of Chlorophyll-a value. It is of great importance to protect the ecological balance of Demirköprü Dam Lake and conduct water quality follow-up studies in order to sustain the utilization of the lake.

\section{Acknowledgment}

The authors thanks for the financial support of İzmir Katip Çelebi University, Department of Scientific Research Project 2015-TYL-FEBE-0022. The author is grateful to Assis. Prof. Dr. Haşim SÖMEK and Fatma Rabia KARADUMAN for their precious assistance.

\section{References}

Akbulut A, Yıldız K. 2001. Mogan Gölü (Ankara) Planktonik Bacillariophyta üyeleri ve dağılımları, Gazi Üniversitesi Fen Bilimleri Enstitüsü Dergisi, 14(4): 99-104.

Alpaslan K, Karakaya G, Küçükyılmaz M, Koçer MAT. 2015. Kalecik ve Cip Baraj Göllerinin (Elazığ) Kıyı Bölgesinde Su Kalitesinin Mevsimsel Değişimi, Yunus Araştırma Bülteni 1:3-10.

Anonymous. 2014. Manisa İli Demirköprü Baraj Gölü Sürdürülebilir Balıkçılık Yönetimi Fizibilite Etüdü, 140.

Arrignon J. 1976. Aménagement ecologique et piscicole des eaux douces, Bordas, Paris, $32 \mathrm{p}$.

Ayvaz M, Tenekecioğlu E, Koru E. 2011. Afşar Baraj Gölü'nün (Manisa-Türkiye) Trofik Statüsünün Belirlenmesi, Ekoloji, 20 (81): 37-47.

Boyd CE, Tucker CS. 1998. Pond aquaculture water quality management, Kluwer Academic Publishers, Norwell, Massachusetts, 685 p. ISBN 978-1-4615-5407-3 (eBook).

Borduqui M, Ferragut C. 2012. Factors determining periphytic algae succession in a tropical hypereutrophic reservoir, Hydrobiologia, 683:109-122. DOI: 10.1007/s10750-0110943-6.

Bremond R, Vuichard R. 1973. Parametres de la qualite des eaux. Documentation Francaise, Paris, $178 \mathrm{p}$.

Buhan E, Koçer MA, Polat F, Doğan HM, Dirim S, Neary ET. 2010. Almus Baraj Gölü $\mathrm{Su}$ Kalitesinin Alabalık Yetiştiriciliği Açısından Değerlendirilmesi ve Taşıma Kapasitesinin Tahmini, Gaziosmanpaşa Üniversitesi, Ziraat Fakültesi Dergisi, 27(1):57-65.

Bulut S, Mert R, Solak K, Konuk M. 2011. Selevir Baraj Gölü'nün Bazı Limnolojik Özellikleri. Ekoloji 20(80): 1322.

Cai Q, Hu Z. 2006. Studies on eutrophication problem and control strategy in the Three Gorges Reservoir, Acta hydrobiologica sinica/Shuisheng Shengwu Xuebao, 30(1): 7-11.

Çevik H, Elibol Mİ. 2009. Yamula Baraj Gölü Limnolojisi, DSİ Genel Müdürlüğü, Ankara, 186.

Dauba F. 1981. Etude comperative de la fauna des poissons dans les ecosystemes de deux reservoirs, Luzech (Lut) et Chastang (Dordogone): These de troisieme cycle L'Institut National Polytechnique de Toulouse, $179 \mathrm{p}$.

Delibacak S, Elmaci OL, Secer M, Bodur A. 2002. Fertility status, trace elements and heavy metal pollution of agricultural land irrigated from the Gediz River, International Journal of Water, 2(2/3): 184-195. DOI: 10.1504/IJW.2002.003194.

DSI. 2015. Devlet Su İşleri Genel Müdürlüğü, http://www.dsi.gov.tr/toprak-ve-su-kaynakları, (Erişim Tarihi: 25.03.15).

Egemen Ö, Sunlu U. 2003. Su Kalitesi Ders Kitab1, Ege Üniversitesi, Su ürünleri Fakültesi, Yayın No: 14, Ege Üniversitesi, Basımevi, Bornova, İzmir, 148.

Giritlioğlu T. 1975. İçme Suyu Kimyasal Analiz Metotları, İller Bankası Yayını, Ankara, No18, 343.

Gürevin C. 2004. Ömerli (İstanbul) Baraj Gölü Su Kalitesi Problemlerinin Araştırılması ve Sürdürülebilir Kullanımı, İstanbul Üniversitesi Fen Bilimleri Enstitüsü Su Ürünleri Temel Bilimler Anabilim Dalı, Yüksek Lisans Tezi, 79.

Göksu MZL. 2015. Su Kirliliği Ders Kitab1, Akademisyen Kitap Evi, Ankara, 200. ISBN 978-605-9942-01-0.

Hakanson L, Jansson M. 1983. Principles of Lake Sedimentology. Springer, Berlin, Volume 70, Issue 3, 320 pp. ISBN 3-540 (Berlin).

Howell BR, Baynes SM. 2004. Abiotic factors. In: Culture of Cold-Water Marine Fish (eds. By E. Moksness, E. Kjorsvik \& Y. Olsen), pp. 7-27. Blackwell Publishing Ltd., Oxford, UK. 
Kırankaya ŞG, Ekmekçi G. 2005. Gelingüllü Baraj Gölü'nde Su Kalitesinin Balık Yaşamı Açısından Değerlendirilmesi, Türk Sucul Yaşam Dergisi. 3(4): 333-340.

Küçükyılmaz M, Örnekçi GN, Uslu AA, Özbay N, Şeker T, Birici N, Yıldız N, Koçer MAT. 2014. Işıktepe Baraj Gölü (Maden, Elazığ) Kıyı Bölgesi Fizikokimyasal Su Kalitesi Üzerine İlk Bulgular, Yunus Araştırma Bülteni, 2: 55-63.

Küçükyılmaz M, Uslu G, Birici N, Örnekçi NG, Yıldız N, Şeker T. 2010. Karakaya Baraj Gölü Su Kalitesinin İncelenmesi, International Sustainable Water and Wastewater Management Symposium, October 2010, Konya, Turkey 2628.

Mutlu E, Aydın-Uncumusaoğlu A. 2018. Analysis of Spatial and Temporal Water Pollution Patterns in Terzi Pond (Kastamonu / Turkey) by Using Multivariate Statistical Methods, Fresenius Environmental Bulletin, 5(27): 29002912.

Mutlu E, Kutlu B, Demir T, Yanık T. 2018. Assessment of metal concentrations and physicochemical parameters in the waters of Lake Tecer, Kastamonu Univ., Journal of Forestry Faculty, 18 (1): 1-10.

Parsons TR, Matia Y, Lalli CM. 1984. A manual of chemical and biological methods for seawater analysis, New York: Pergamon Press, 173.

Sarıyıldız A, Harmancıoğlu N, Sılay A, Çetin HC. 2008. Gediz Nehri Su Kalitesi Parametrelerinin Eğilim Analizi, Çevre ve Orman Bakanlığı, Devlet Su İşleri Genel Müdürlüğü, 5. Dünya Su Formu Bölgesel Hazırlık Süreci Türkiye Bölgesel su Toplantıs1, Havza Kirliliği Konferans1, 603-611.

SKKY. 2004. Su Kirliliği Kontrol Yönetmeliği, 31.12.2004 Tarih ve 25687 Say1lı Resmi Gazete, Ankara.

Starling FLRM. 1993. Control of eutrophication by silver carp (Hypophthalmichthys molitrix) in the tropical Paranoá (Brasilia, Brazil); a mesocosm experiment. Hydrobiologia, 257(3): 143-152.

Stirling HP. 1985. Chemical and Biological Methods of Water Analysis for Aquaculturalists. Institute of Aquaculture, University of Stirling, 119. ISBN 0952119854.

Strickland JDH, Parsons TR. 1972. A Practical Handbook of Seawater Analysis, 2nd ed. Bulletin, vol 167 Ottowa: Fisheries Research Board of Canada, 310.

Sömek H. 2011. Adıüzel Baraj Gölü'nün (Güney-Denizli) Fitoplankton Kompozisyonu ve Mevsimsel Değişimi, Ege Üniversitesi Fen Bilimleri Enstitüsü $\mathrm{Su}$ Ürünleri Temel Bilimler Anabilim Dalı, Doktora Tezi, 119.
Sömek H, Balık S, Ustaoğlu MR. 2005. Topçam Baraj Gölü (Çine-Aydın) Fitoplanktonu ve Mevsimsel Değişimleri, Süleyman Demirel Üniversitesi, Eğirdir $\mathrm{Su}$ Ürünleri Fakültesi Dergisi, 1(1): 26-32.

Sümbüloğlu K, Sümbüloğlu V. 2010. Biyoistatistik, Hatiboğlu Yayınevi, 14. Bask1, 299. ISBN 9757527122.

SWQMR. 2015. Surface Water Quality Management Regulation, 15.04.2015 Date and Nr. 29327 TR Official Newspaper, (in Turkish), Ankara.

Tanyolaç J. 2009. Limnoloji (Tatlısu Bilimi), Hatiboğlu Yayınevi, Ankara, 264. ISBN 9789757527466.

Taş B, Çetin M. 2011. Gökgöl (Ordu-Türkiye)'ün Bazı FizikoKimyasal Özelliklerinin İncelenmesi, Ordu Üniversitesi, Bilim ve Teknoloji Dergisi, 1(1): 73-82.

Taş B. 2006. Derbent Baraj Gölü (Samsun) Su Kalitesinin İncelenmesi. Ekoloji Dergisi 15(61): 6-15.

Taylor WD, Lambou VW, Williams LR, Hern SC. 1980. Trophic state of lakes and reservoirs, USEPA Technical Report E-80-3, 15 p.

Tepe Y, Boyd CE. 2003. A reassessment of nitrogen fertilization for sunfish ponds, Journal of World Aquaculture Society, 34 (4): 505-511.

Tenekecioğlu E. 2011. Demirköprü Baraj Gölü’nde (Manisa) Mevsimsel Plankton Topluluk Yapısı Değişimleri, Ege Üniversitesi Fen Bilimleri Enstitüsü Su Ürünleri Yetiştiricilik Anabilim Dalı, Doktora Tezi, 146.

Thornton KW, Kimmel BL. Payne FE. 1990. Reservoir Limnology: Ecological Perspectives. John Wiley \& Sons, New York, 246. ISBN 0-471-88501-O.

Uslu O, Türkman A. 1987. Su Kirliliği ve Kontrolü, T.C. Başbakanlık Çevre Genel Müdürlüğü Yayınları Eğitim Dizisi 1 Ankara 364.

Varol M. 2015. Dicle Baraj Gölü Su Kalitesinin Su Kirliliği Kontrolü Yönetmeliği'ne Göre Değerlendirilmesi, Türk Tarım ve Doğa Bilimleri Dergisi, 2(1): 85-91.

Varol M. 2013. Batman Baraj Gölü'nün Trofik Durumunun Belirlenmesi, Anadolu Doğa Bilimleri Dergisi 4(2): 51-59.

Walling DE, Webb BW. 1986. Solutes in river systems. In: Solute processes, ST Trudgill (edi.) Chischester: John Wiley \& Sons. 251-327.

Wetzel RG. 1983. Limnology, 2nd Edition. Saunders College Publishing, Philadelphia, 860.

Wetzel RG. 2001. Limnology: Lakes and River Ecosystems. Academic Press, London, 1006.

Wood RD. 1975. Hydrobotanical methods, University pf Paris Press, London, 173. 